\title{
Windstorm Resilient Rural Housing: Lessons learned in Temerloh, Malaysia
}

\author{
Foong Sin Lam¹, Jer Vui Lee², Yeok Meng Ngeow³ \\ ${ }^{1}$ Department of Civil Engineering, ${ }^{2}$ Department of Mechanical Engineering, Faculty of Engineering \& Science, \\ ${ }^{3}$ Department of General Studies, Faculty Creative Industries, \\ Universiti Tunku Abdul Rahman, Malaysia \\ lamfs@utar.edu.my; leejv@utar.edu.my; ngeowym@utar.edu.my \\ Tel: +60123787129
}

\begin{abstract}
In 2019 alone, Temerloh district located in central Peninsular Malaysia has been hit by unpredictable wind storms in localised areas which damaged more than 185 rural homes. This research set out to assess the structural vulnerabilities of damaged rural houses to severe winds in Temerloh and lessons learned from windstorm damage through field surveys of damaged homes between March 2019-August 2019 and supplemented by districtlevel post-windstorm reconnaissance reports prepared by Malaysia Civil Defense Force (APM) and other information gathered from local government. Results indicate poor performance of structural and non-structural building components in resisting high wind loads due to inadequate design, understrength of failed building materials and defective construction details. The results of this study could have important implications for government agencies, NGOs, builders, and engineers in assisting rural communities in reconstructing windproof resistant homes and planning for future windstorm risk management efforts specially catered to homeowners in Temerloh.
\end{abstract}

Keywords: Rural housing; Windstorm; Resilience; Malaysia

eISSN: 2398-4287 @ 2019. The Authors. Published for AMER ABRA cE-Bs by e-International Publishing House, Ltd., UK. This is an open access article under the CC BYNC-ND license (http://creativecommons.org/licenses/by-nc-nd/4.0/). Peer-review under responsibility of AMER (Association of Malaysian Environment-Behaviour Researchers), ABRA (Association of Behavioural Researchers on Asians) and cE-Bs (Centre for Environment-Behaviour Studies), Faculty of Architecture, Planning \& Surveying, Universiti Teknologi MARA, Malaysia.

DOI: https://doi.org/10.21834/e-bpj.v4i12.1817

\subsection{Introduction}

Turbulent surface wind with frequent afternoon and evening showers accompanied by thunder and lightning prevail during Malaysia's inter-monsoon periods. These localised microscale thunderstorms last for a short time but capable of producing strong winds that cause damage to properties and uproot trees (Nor et al., 2018). Windstorm damage to houses is primarily due to extreme wind speed, flying debris and impact from fallen trees. The roof of a house is the highest component above the ground; therefore, it is most susceptible to windstorm damage. Any damage to any parts of the roof will allow wind to enter the house creating higher internal pressure that will lift the roof off from its support and connections (He J. et al., 2017). Past damage investigations for windstorm events have revealed factors in poor building performance, particularly in the case of non-engineered rural houses in Malaysia. Several studies have reported that windstorm caused greatest catastrophic damages to rural homes in Malaysia that occurred with failure of roof connections and roof uplift (Deraman et al., 2019; Yahya, 2019; Zaini et al., 2017; Muhammad et al., 2015; Ramli et al., 2014).

Immediately after windstorm strikes, a team of field inspectors and engineers must assess all damages, safety and risk level of the buildings. The current post-damaged assessments in Temerloh district documented only photographic evidence of non-structural damaged components such as damages to the roof covering while it did not report structural damages.

Several countries have implemented various methods for post-damage inspection and rapid building assessment. Countries which adopt standard damage assessment methodology are Japan (JBDPA 90-91), the USA (ATC 20, ATC20-2), New Zealand (NZNSEE 98), the Balkans and Italy (UNDP / UNIDO, Greece). These building damage assessments methods are developed primarily for post-

eISSN: 2398-4287 @ 2019. The Authors. Published for AMER ABRA cE-Bs by e-International Publishing House, Ltd., UK. This is an open access article under the CC BYNC-ND license (http://creativecommons.org/licenses/by-nc-nd/4.0). Peer-review under responsibility of AMER (Association of Malaysian Environment-Behaviour Researchers), ABRA (Association of Behavioural Researchers on Asians) and cE-Bs (Centre for Environment-Behaviour Studies), Faculty of Architecture, Planning \& Surveying, Universiti Teknologi MARA, Malaysia. DOI: https://doi.org/10.21834/e-bpj.v4i12.1817 
earthquake damage assessments, and they adapted the USA (ATC-45) field evaluation for a safety evaluation after windstorm and floods (ATC, 2005). The content of the forms used in Japan, New Zealand and USA methods are practically the same. The method used in the Balkans required a more detailed form, and field surveyors need to undergo training to understand structural building behaviour before being able to apply the method (Rosetto et al., 2010). Therefore, we adopted the USA method of evaluating windstorm damages in this study. Damage assessments help to identify the mode of failures of structural members accurately, and engineers can propose stronger design alternatives and government/NGOs and distribute appropriate monetary assistance to rebuild more wind resilient homes.

This study focuses on damage assessment to rural housing in Temerloh district located in central Peninsular Malaysia. Unpredictable wind storms have hit localised areas in Temerloh which damaged more than 185 rural homes between March to August 2019. Based on the rapid and detailed damage evaluations, major typical failure modes and statistical patterns in terms of severity of structural and non-structural damages are evaluated and presented. This study involved the use of field surveys, ground data and photographic evidence to perform structural damage assessments for the houses. Recommendations and lessons learned are proposed based on the findings of this study. These recommendations may be used for the design and reconstruction purposes to mitigate the effect of future windstorm events.

\subsection{Methodology}

Field surveys were carried out by a team of evaluators led by Malaysian Civil Defense Force from Mar 2019 to August 2019, which caused damages to rural houses in Temerloh district. Figure 1 shows the location map of Temerloh with surveyed locations of the damaged houses. The survey team consists mainly of officers from District and Land Office, Public Welfare Department, Malaysian Civil Defense Force (APM) and Malaysian Armed Forces. The survey team walked through the areas affected by the windstorm and photographed damaged houses/buildings. The items included in the post-windstorm damage surveys were the name, address, time, date, persons attended the surveys and estimated damage costs. Another field surveys were conducted on the $29^{\text {th }}$ and $30^{\text {th }}$ August by researchers from the Centre of Disaster Risk Reduction (CDRR), UTAR.

Due to the absence of proper structural damage assessments tools in the field surveys, we thus applied structural damage assessments on selected 135 houses of the 185 damaged rural houses in villages in Temerloh using photographic documentation provided by APM and field surveys by authors and researchers from CDRR. For each of the housing stocks, damages brought about by windstorm were observed mainly on structural and non-structural components that are most susceptible to wind pressure such as vertical and horizontal structural and roof framing, roof sheathings, walls and windows. This study involves two-levels building-level housing damage assessment based on Applied Technology Council's procedure ATC-45 (ATC, 2005; Rosetto et al., 2010), questionnaire survey and district-level post-windstorm incident reports and damage pictures prepared by Malaysia Civil Defense Force (APM). The two-level building damage assessments are:

1. Rapid evaluation: This first level of assessment requires classification of the selected rural houses by quickly colour tagging the buildings based on the usability and damage states of the buildings, as shown in Table 1. Other qualitative damage description includes partial collapse, structural leaning, facade damage, roof damage, falling hazards, ground movement and differential settlement.

2. Detailed evaluation: This second level of assessment involves a detailed engineering evaluation of the selected damaged building using observed damage criteria shown in Table 2. The detailed assessment included the following: collapse, out of plumb, falling hazard due to damage, geotechnical hazard, electrical lines/leaning trees/submerged fixtures, structural vertical and lateral load-bearing components and joint failures and the degree of damage in non-structural components

We conducted interviews to assess the use of mitigation measures during reconstruction. We adopted the questionnaire survey designed by Lotay (2015) and Yamane (2013). The field survey contained questions addressing the following areas of concerns: roof cover inclination and materials, connection materials and between roof purlins, rafters and roof cover, frequency and damage extent of past windstorm event, presence of trees around the house, roof overhang, change of materials and construction practice during reconstruction.

Table 1. Definitions of posting categories in Rapid Evaluation

\begin{tabular}{ll}
\hline Rapid Evaluation Criteria & \multicolumn{1}{c}{ Description } \\
\hline $\begin{array}{l}\text { Safe/No danger } \\
\text { (Green-tagged) }\end{array}$ & $\begin{array}{l}\text { No apparent hazard found. No restriction on use or } \\
\text { occupancy. No falling hazards }\end{array}$ \\
$\begin{array}{l}\text { Restricted Use } \\
\text { (Yellow-tagged) }\end{array}$ & $\begin{array}{l}\text { Hazardous conditions exist that require a restriction on } \\
\text { the occupancy and use of the structure. Falling hazard, } \\
\text { ceiling and walls are water-saturated, façade damage }\end{array}$ \\
$\begin{array}{l}\text { Unsafe } \\
\text { (Red-tagged) }\end{array}$ & $\begin{array}{l}\text { Hazards present and unsafe } \\
\text { for occupancy and entry, risk of collapse, ground } \\
\text { movement \& differential settlement, structural leaning }\end{array}$ \\
\hline
\end{tabular}




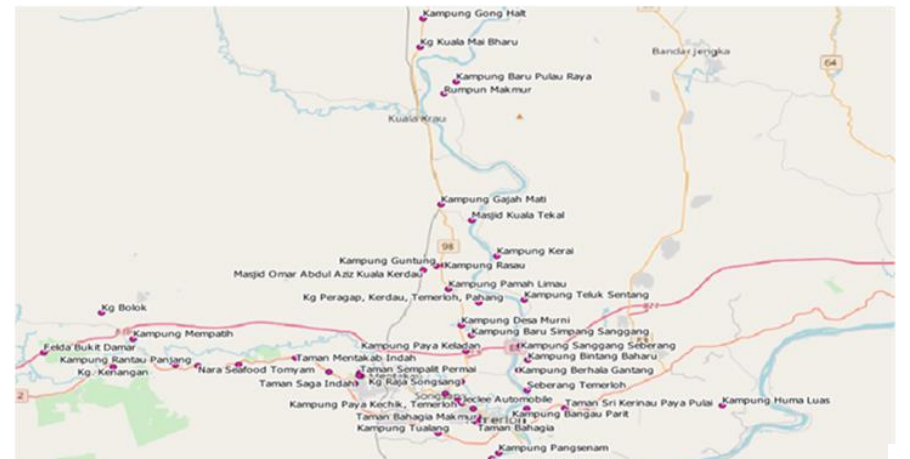

Fig. 1. shows the location map of Temerloh with surveyed location of the 185 damaged windstorm rural houses

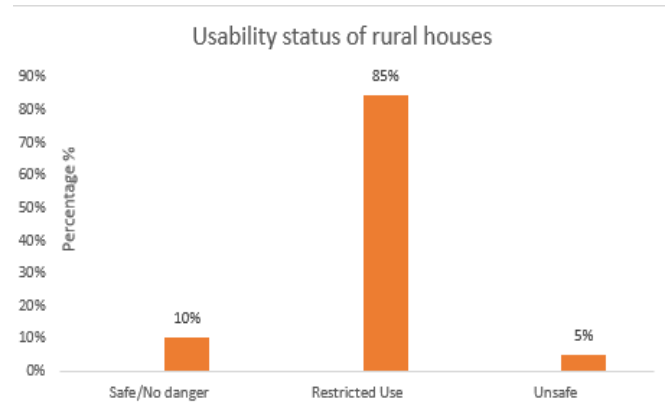

Fig. 2. Usability status of rural houses

\subsection{Findings}

\subsection{Summary of Damage Observations and Typical Structural Failure Modes from Rapid Evaluation Methodology}

The majority of the houses surveyed showed designs of typical of the 'Rumah kampung' styles and low-cost single-storey terrace houses. 'Rumah kampong' are typically closely-clustered 1 to 2 story structures constructed with wood frame on the post with wooden walls, metal corrugated or zinc-roofed raised on stilts or ground. Single-storey terrace houses are typically reinforced concrete frame structure with brick walls, roof truss roofing and asbestos ceiling boards.

We present the results of the status of usability of the buildings using rapid evaluations as shown in Figure 2. According to Figure $2,10 \%$ of the inspected buildings were safe for occupancy. Approximately $85 \%$ of the houses that requires restrictions placed on areas of the buildings that were not usable. $5 \%$ of the houses were unsafe, and the residents seek shelter temporarily at their neighbours and relatives homes. There was no major collapse. Based on the district-level post-windstorm incident reports and damage pictures, the primary identified causes of damage throughout the community were wind effect. A small percentage of the reported buildings suffered damage due to flying debris from neighbouring roof materials and toppled trees.

Based on the rapid evaluations, we identified and defined major typical failure modes of all the damaged houses evaluated based on photographic evidence, as shown in Figure 3-4. For each of the typical structural failure modes, we included a sample representative photograph, and a summary of posting (Safe, Restricted Use or Unsafe) and we presented a description of possible causes of failure under each figure.

Typically damaged roof sheathings were $0.18 \mathrm{~mm}$ thick corrugated zinc roof sheets attached by roof nails to timber trusses. Interviews with homeowners showed that thicker sheathings did not replace these thin corrugated during repair and replacement after the windstorm. Wind uplift caused roof sheathings to displace a distance away, but most of the walls remained intact. Based on observations of roo debris, roof nails and sheathings were rusty. Rust decreased nail strength that caused roof sheathings to pull out from the rusted connections.

One of the main observation from the field survey was that older building experienced more severe damage compared with newer homes. Figure 8(a) shows an older and newer located in the vicinity of the area, with the older home experienced severe damage. In contrast, the newer building with a newly built roof system did not experience any damage. The older home experienced damage to external facade. The poor conditions of the zinc roof and poor connections could not withstand the higher than average wind speed. Some properties have a second story provide shelter during a strong windstorm and protection from flying debris and fallen trees and branches. The time to start repair work was slow due to lack of workforce.
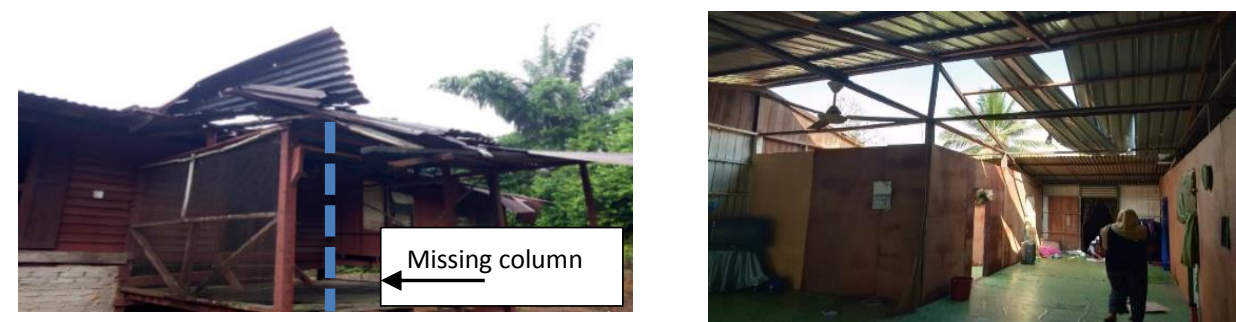

Fig. 3. (a) Loss of vertical column support and overhang roof damage; Post Restricted Use with barricade the front portion (b) Purlin and rafter section sizes were inadequate and purlin-rafter connection failure and roof blown away) Damaged interior contents due to broken fallen roof sheathings; rain water intrusion; Post Unsafe with falling hazard 

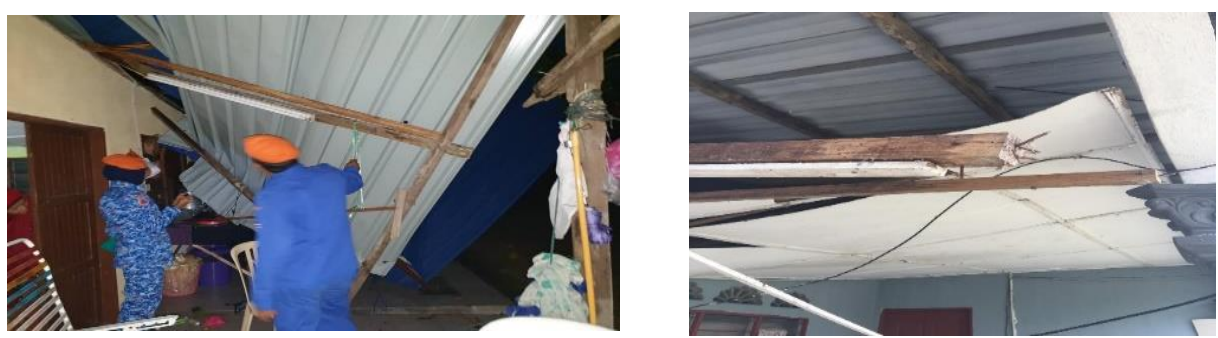

Fig. 4. (a) Roof sheathing damage due to overturning failure mode at roof edges and absence of cross bracing;Post Restricted Use and barricade the side of the house (b) Weak and rusted nail connections

\subsection{Summary of Damage Observations and Typical Structural Failure Modes from Detailed Evaluation Methodology}

We summarised the results of the detailed evaluation in Table 2. Figure 5 and 6 show the results of the detailed evaluation of statistical patterns in percentage values in terms of the severity of structural and non-structural damages. Damage to structural parts includes column vertical and lateral load-bearing components such as columns, beams, load-bearing walls, roof and floor framing and their connections. Non-structural components consist of ceilings, roof sheathings/shingles and connections, fallen/leaning trees, walls and window. Figure 7 illustrates that $78 \%$ of the houses experienced minor structural damage, whereas $18 \%$ experienced moderate and $4 \%$ severe structural damage. We found that most minor structural damages occurred in the roof system and connections where homeowners need to replace several timber roof beams and purlins. Figure 8 showed that $27 \%$ of the houses experienced minor nonstructural damage, $62 \%$ experienced moderate non-structural damage, and $11 \%$ experienced severe non-structural damage.

Table 2. Summary of detailed evaluation results

\begin{tabular}{lccc}
\hline Detailed Evaluation Criteria & Minor & Moderate & Severe \\
\hline $\begin{array}{l}\text { Geotechnical hazards (slope failure, settlement, ground } \\
\text { movement) }\end{array}$ & 0 & 0 & 0 \\
$\begin{array}{c}\text { Structural system damage/misalignment } \\
\quad \text { Vertical load carrying system - bracing, columns, load }\end{array}$ & 1 & 1 & 0 \\
$\quad$ bearing walls, beams & 1 & 0 & 0 \\
$\quad$ Horizontal load carrying system - bracing, moment frame & 106 & 24 & 6 \\
$\quad$ Roof/floor framing and their connections & & 35 & 20 \\
Non-structural & 20 & 96 & 3 \\
$\quad$ Cillings & 40 & 10 & 2 \\
$\quad$ Roof sheathing/shingles and connections & 2 & 10 & 2 \\
$\quad$ Fallen/Leaning trees & 5 & & \\
$\quad$ Walls and windows & & & \\
\hline
\end{tabular}

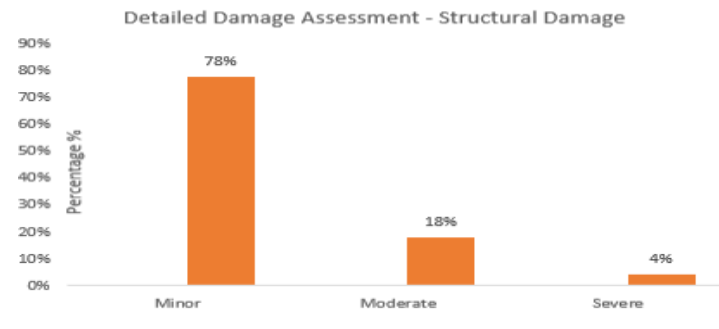

Fig. 5. Detailed assessment and statistical patterns in terms of severity of structural damage

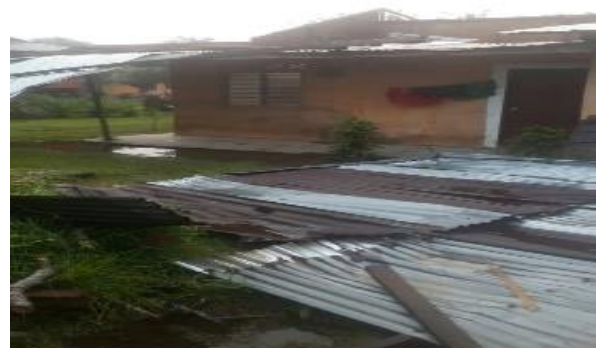

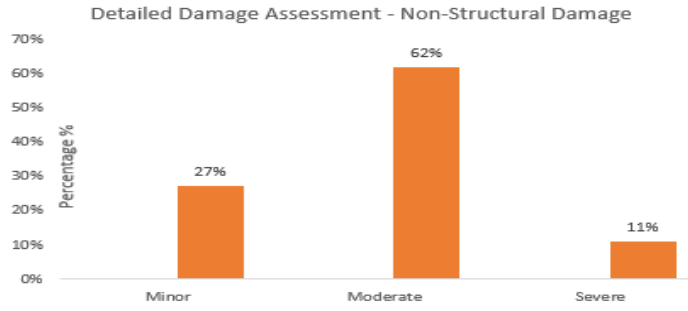

Fig. 6. Detailed assessment and statistical patterns in terms of severity of non-structural damage

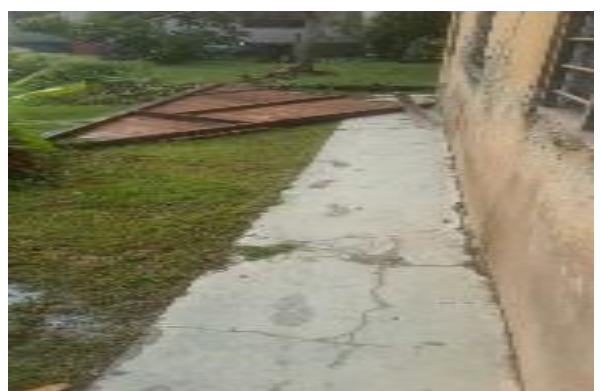

Fig. 7. (a) Roofing damage and transported a distance away due to failure of poor connection and use of lightweight zinc materials creating higher net uplift forces (b) Loss of wall frame due to poor connections between wood and brick wal (Source: Field survey reports by APM)

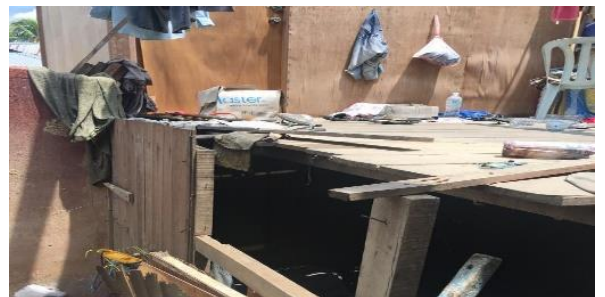




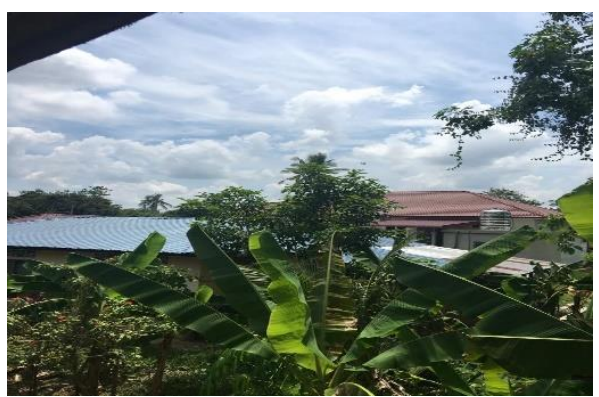

Fig. 8. (a) Adjacent rural homes with newly built roof with thicker roof sheathings did not experience any damage (b) Wind damage to interior walls and possibilities of damage to vertical support structural system when the roof was breached
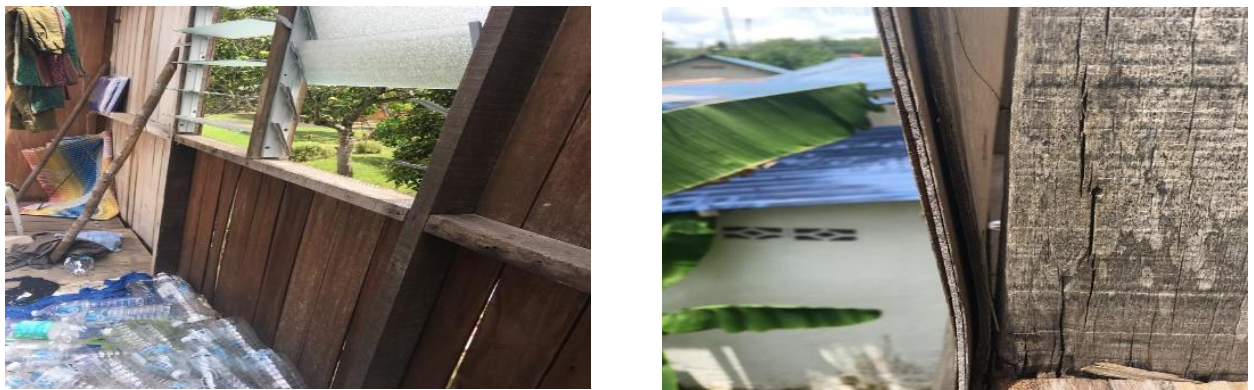

Fig. 9. (a) Damage to windows \& (b) Plywood separation from structure
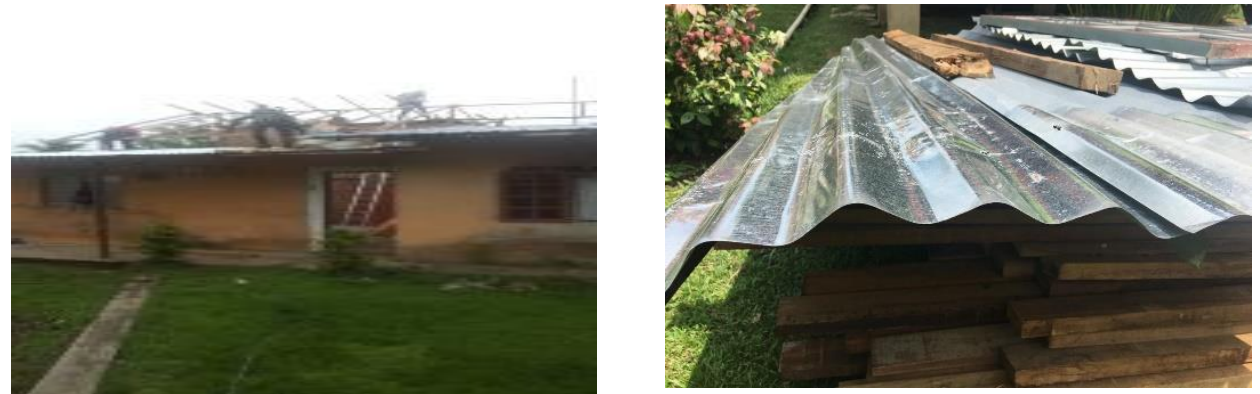

Fig. 10. (a) Repair work undertaken by Malaysian Armed Forces (b) There's no change in material used in house reconstruction (Source for Fig. 9-12: Field survey photo taken during authors' visit on $30^{\text {th }}$ August 2019)

The results are consistent with a study carried out by Majid et al. (2010) who identified that $47 \%$ of rural houses had damage in roof sheathings (non-structural), 30\% damage in roof supporting system (structural) and $13 \%$ damage on roof shingles (non-structural) in rural houses in Peninsular Malaysia. We found no geotechnical hazards. Figure 7-10 show major structural and non-structural damage mechanisms.

\subsection{Key recommendations}

Based on field surveys and findings from this study, we recommend some structural strengthening that can be adopted to rebuild better windstorm resilient rural housing. Thin roof sheathings need to be replaced by locally manufactured thicker roof sheathings. At least $0.38 \mathrm{~mm}$ or more in thickness painted with durable zinc coating to replace the $0.18 \mathrm{~mm}$ thick corrugated zinc sheets used in older houses (IFCR-SRU, 2017). More substantial and closer roofing screws are the preferred fasteners (diameter $=20 \mathrm{~mm}$ ) to prevent roof uplift subject to strong winds (IFCR-SRU, 2017). From findings, builders used small, smooth-shank roofing nails. Laboratory work done by Wan Chik (2013) confirmed the findings. For a maximum wind speed of $53.7 \mathrm{~km} / \mathrm{h}$ in selected study areas in rural Malaysia, screw fasteners resisted much higher pull force than nail fasteners at a spacing of $850 \mathrm{~mm}$ between purlin and roof sheathings. Cross bracings in rafters and trusses prevent overturning and provide load path for lateral wind loads to the transferred to the foundation. Hipped roofs have a better aerodynamic performance of wind results in lower suction pressure compared to gable and mono-pitched roofs (IFCRSRU, 2017). More massive overhangs have more substantial wind pressures as seen in some of the damaged roofs.

One of the steps towards improving rural housing performance in high wind events is through improvements to building code compliance, construction guidelines and practices. Malaysia's rural housing stocks are non-engineered buildings that are constructed informally without input from qualified architects and engineers in the design and construction stages. We recommend that communities should have access to code-compliance technical advice from building professionals. Chik et al. (2019) found out that mitigation 
measures such as an amendment to wind speed and wind code and enforcement by authorities on wind resistance requirements in rural building approval process were the most favoured key measures by building professionals in Malaysia (Chik, 2019).

Other than structural strengthening, increased community social resilience such as awareness, knowledge and skill can limit the damage (Bastaminia, 2019). Homeowners were thankful to Malaysian Armed Forces who helped them in the house reconstruction work. Due to the lack of sufficient workforce and labour, urgent work is done hastily without seeking advice from qualified engineers. Therefore, it is necessary to upgrade the essential technical skills of builders through training programs. Interview with the homeowners revealed that they do not know about future windstorm protection. Therefore workshops will help to raise awareness on the danger of future occurrences. A detailed damage assessment has a significant advantage compared to current post-damaged assessments carried out by the Malaysian Civil Defense Force. Decision-makers can access the detailed damaged assessments to manage windstorm disaster effectively. Building professionals can create plans to train personnel in administering damage assessments forms before disaster strikes. Relevant government officials and agencies and local communities can access these damage data easily.

On the other hand, the higher the economic resilience, the lower the economic loss and the speedier the recovery. Research showed that households with more considerable savings have a higher recovery rate (Walsh, 2019). Field survey interview on $30^{\text {th }}$ August 2019 with a female homeowner revealed repair work by the homeowner in one of the houses has not been started due to lack of financial resources. We visited the damaged home about three months after the damage had occurred. The damaged roof has not been removed and is at risk of falling posing a threat to the residents. We recommend that low-income villagers develop an awareness of future climate threats and rural economy stimulation will help at-risk communities to be more resilient.

Though this study was able to identify the severity of structural and non-structural damages due to windstorm using building damage assessment process, the research is not without limitations. The field surveys were not carried out with qualified building design professionals. Some critical damages may not have been reported in the field surveys reports that are important for a detailed assessment analysis. Not all affected homeowners could be contacted. Therefore their responses on building back better homes could not be captured. Only selected photographic evidence were provided for the house.

\subsection{Conclusion}

Damage to roof sheathings and non-structural components were the main failure modes observed in rural houses in Temerloh due to high wind speed events. Inadequacy in design and material deterioration increased the building physical vulnerability of rural houses, and due to low financial income, they cannot afford to build back more post-windstorm resilient houses. The age and quality of materials used played a significant role in the response of the rural houses to localised high wind loads. We recommend researchers undertake an evaluation in assessing the differences and similarities in the process of collecting post- damaged data among several districts and states in Malaysia and in assessing how local communities and other stakeholders use these damage assessment data in disaster management. These data is useful in local disaster preparedness plans to identify vulnerable areas of community and recommend mitigation actions to reduce risks. Therefore it is recommended that building surveyors carry out the detailed damage assessment to accurately assess failure patterns for economic loss assessment analysis.

\section{Acknowledgements}

Due acknowledgements are given to the team from Temerloh District Malaysian Civil Defense Force and UTAR Disaster Risk Reduction Centre whom the authors worked with for the data collection.

\section{References}

ATC (Applied Technology Council). (1989a). Field Manual: Post-earthquake Safety Evaluation of Buildings Detailed evaluation safety assessment form. ATC-20. Redwood City, CA: ATC. ATC (Applied Technology Council).

ATC (Applied Technology Council). 2004. Field Manual: Safety Evaluation of Buildings after Windstorm and Floods. ATC-45. Redwood City, CA: ATC. ATC (Applied Technology Council).

Bastaminia, A., Rezaei, M. R., \& Saraei, M. H. (2017). Evaluating the components of social and economic resilience: After two large earthquake disasters Rudbar 1990 and Bam 2003. Jàmbá: Journal of Disaster Risk Studies, 9(1), 1-12.

Chik, F. W., Majid, T. A., \& Zakaria, S. A. S. (2019, February). Expert awareness of wind disaster risk reduction in Northern Peninsular Malaysia. In IOP Conference Series: Earth and Environmental Science (Vol. 244, No. 1, p. 012018). IOP Publishing.

Construction Industry Development Board Malaysia (CIDB). Quality assurance for prefabricated steel roof truss system. (2009). Retrieved from http://www.cidb.gov.my/images/content/pdf/cis/cis12.pdf

Deraman, S. N. C., Majid, T. A., Zaini, S. S., Yahya, W. N. W., Abdullah, J., \& Ismail, M. A. (2019, February). Numerical investigation on the air flow characteristics of a core house with the presence of kitchen house using computational fluid dynamics. In IOP Conference Series: Earth and Environmental Science (Vol. 244, No. 1, p. 012030). IOP Publishing.

He, J., Pan, F., \& Cai, C. S. (2017). A review of wood-frame low-rise building performance study under hurricane winds. Engineering Structures, $141,512-529$. 
International Federation of the Red Cross and Red Crescent societies - Shelter Research Unit (IFCR-SRU). How to build safe roofs with corrugated galvanized iron (CGI) sheeting. (2017). Retrieved from https://www.sheltercluster.org/sites/default/files/docs/ifrc-sru_cgi-roofing_manual_e-version_high-res.pdf

Lotay, Y., \& Center, A. D. R. (2015). Wind Induced Damage to Roofs and Mitigations: A Comparative Study on Roofs in Bhutan and Japan.

Majid, T. A., Ramli, N. I., Ali, M. I., Saad, M. S. H., Hashim, M., and Zakaria, I. 2010 Malaysia Country Report 2010.

Marshall, T. P., Bunting, W. F., \& Weithorn, J. D. (2003). 2.1 PROCEDURE FOR ASSESSING WIND DAMAGE TO WOOD-FRAMED RESIDENCES.

Zisis, I., Raji, F., \& Candelario, J. D. (2016). Large-scale wind tunnel tests of canopies attached to low-rise buildings. Journal of Architectural Engineering, 23(1), B4016005.

Mohd, T., Saraf, M. H. M., Pin, S. F. B. C., \& Hasbullah, M. N. (2016). Designing the invention house assessment form for Kuala Krai, Malaysia. Procedia-Social and Behavioral Sciences, 234, 317-325.

Mohit, M. A., \& Sellu, G. M. (2017). Development of Non-structural Flood Mitigation Policies and Measures for Pekan town, Malaysia. Asian Journal of Behavioural Studies, 2(6), 9-20.

Muhammad, M. K. A., Majid, T. A., Ramli, N. I., Deraman, S. N. C., Chik, W., \& Alwani, F. (2015). An Overview of Non-Engineered Buildings Roofing System failure under Wind Loads. In Applied Mechanics and Materials (Vol. 802, pp. 89-94).

Nor, M., \& Bin, M. F. F. (2018). Understanding the development of inter-monsoon convective storms over the Western Peninsular Malaysia (Doctoral dissertation, University of Reading).

Ramli, N. I., Majid, T. A., Chik, F. W., Muhammad, M. K. A., \& Deraman, S. C. (2014). Assessment of pull-through failure of nail connection for rural roofing system under wind load in Malaysia. Journal of Civil Engineering Research, 4, 135-137.

Rossetto, T., Kappos, A. J., Kouris, L. A., Indirli, M., Borg, R. P., Lloyd, T. O., \& Sword-Daniels, V. (2010). Comparison of damage assessment methodologies for different natural hazards. Urban habitat constructions under catastrophic events (Proceedings).

Taranath, B. S. (2009). Reinforced concrete design of tall buildings. CRC press

Trans Tech Publications.Petty, S. E. (Ed.). (2017). Forensic engineering: Damage assessments for residential and commercial structures. CRC Press.

Walsh, B. J., \& Hallegatte, S. (2019). Measuring Natural Risks in the Philippines: Socioeconomic Resilience and Wellbeing Losses.

Wan Chik, F. A., Ramli, N. I., Muhammad, M. K. A., \& Majid, T. A. (2013). THE EFFECT OF WIND LOAD ON RURAL ROOFING SYSTEM.

Yahya, W. N. W., Zaini, S. S., Majid, T. A., Ismail, M. A., Deraman, S. N. C., \& Abdullah, J. (2019, February). Numerical investigation on the effects of wind direction to the air flow characteristics surrounding an isolated rural house. In IOP Conference Series: Earth and Environmental Science (Vol. 244, No. 1, p. 012031). IOP Publishing.

Yamane, Y., Kiguchi, M., Hayashi, T., Dewan, A., \& Terao, T. (2013). Characteristics of damages of severe local storms based on field surveys in Bangladesh. Journal of Disaster Research, 8(6), 1052-1053.

Zaini, S. S., Majid, T. A., Deraman, S. N. C., Chik, F. A. W., \& Muhammad, M. K. A. (2017). Post Windstorm Evaluation of Critical Aspects Causing Damage to Rural Houses in the Northern Region of Peninsular Malaysia. In MATEC Web of Conferences (Vol. 103, p. 03016). EDP Sciences. 